\title{
CHALLENGES FACING ISLAMIC BANKING IN IRAN: EVALUATION AND POLICY IMPLICATIONS
}

\author{
Hossein Meisamy ${ }^{1}$ and Hassan F. Gholipour ${ }^{2}$ \\ ${ }^{1}$ The Monetary and Banking Research Institute (MBRI), Iran, h.meisamy@mbri.ac.ir \\ ${ }^{2}$ Swinburne University of Technology, Australia, hgholipour@swin.edu.au
}

\begin{abstract}
Iran is one of the few countries that has instituted shariah-compliant banking nationwide and does not have a conventional banking sector. However, since the RibaFree Banking Act (RFBA) was passed and put into practice in 1983, the Iranian Islamic banking system has experienced some significant challenges and shortcomings. The main purpose of this paper is to identify the various impediments facing the Iranian Islamic banking industry and to suggest a prioritized listing of these challenges. To achieve this goal, a three-round Delphi study (a method designed to aid consensus building) is used to determine the major challenges and rank them based on relative importance. The research panel consulted consists of 32 Iranian Islamic banking experts with in-depth knowledge and experience. The results show that the top five challenges to the Islamic banking system in Iran are (1) the governmental attitude towards Islamic banking; (2) lack of competition; (3) not revising the law (RFBA); (4) lack of shariah supervision; and (5) lack of accounting and auditing standards. This paper contributes to the literature addressing Islamic banking by critically analysing the more than three decades of Iranian experience in implementing shariah-compliant banking.
\end{abstract}

Keywords: Islamic banking, Iran, Delphi approach, Iranian Riba-Free Banking Act. JEL Classification: D53; E52; G20.

\author{
Article history: \\ Received : April 21, 2020 \\ Revised : June 9, 2020 \\ Accepted : July 12, 2020 \\ Available online : August 25, 2020 \\ https://doi.org/10.21098/jimf.v6i3.1241
}




\section{INTRODUCTION}

\subsection{Background}

Iran is one of the pioneers in developing the theoretical foundations of Islamic banking and putting this new banking model into practice (Nili, 2014, p. 14 ). The rise of Islamic banking in Iran began soon after the Islamic Revolution of 1979, gradually transforming the conventional practices of the country's banking sector into an integrated framework in which all operations comply with shariah law. In 1983, the Iranian parliament passed the Riba-Free Banking Act (RFBA). However, Iran's lack of constructive interaction with other countries has impeded the effective introduction of its banking framework abroad (Central Bank of Iran, 2017, p. 11).

During its more than three decades of operations, the Iranian Islamic banking system has encountered significant challenges, opportunities, and successes. In this regard, one should note that the Iranian experience is very different from other Islamic countries, such as Malaysia and Indonesia, in which dual-banking systems containing both Islamic and conventional operations are practised. In a dual-banking system, Islamic banks are in competition with conventional banks and seek to keep and accommodate customers in a variety of ways (e.g. reporting the activities carried out in pursuing shariah compliance and paying attention to social activities). However, this competition does not exist in the single Islamic banking system in place in Iran (Gudarzi Farahani \& Sadr, 2012, p. 13).

This paper evaluates the challenges facing the Islamic banking system in Iran and ranks these challenges based on experts' views and building consensus via a three-round Delphi study. The respondents are 32 Iranian Islamic banking experts who have in-depth knowledge and experience of the industry.

Acknowledging the important challenges to the Islamic banking system would help Iranian policymakers to devise solutions that ultimately result in better implementation of its banking system. This would, in turn, lead to banking stability and improved access for the Iranian population to better financial products ${ }^{1}$.

It should be noted that, unfortunately, very little research has been done in the field of Islamic finance with reference to the Iranian model of riba-free (usuryfree) banking. In other words, although the Islamic banking industry is currently spreading fast through many Islamic and non-Islamic countries, and hence research in the field is also growing, very few papers and books have been written about the Iranian experience of conducting shariah-compliant banking over its more than three decades of existence. Evaluating the challenges of Islamic banking in Iran is, therefore, the main topic of this research.

\subsection{Objective}

The objective of the present paper is to critically analyse the Iranian experience in implementing shariah-compliant banking and to develop an ordered listing of the challenges faced by the industry.

1 Many researchers have shown that Islamic banking affects financial stability positively (Rashid et al., 2017, p. 13). 


\section{LITERATURE REVIEW}

\subsection{Background Theory}

The theoretical basis that support this paper is the 'theory of riba-free banking'. This is a special model of Islamic banking in which the focus is solely on the issue of eliminating riba from the banking industry (Iqbal \& Mirakhor, 2011, p. 23; Zubair, 2014, p. 65). This model was first presented by Martyr Al-Sayyid Muhammad Baqir al-Ṣadr (1934-1980) in his book entitled Al-Bank al-la Ribawi fi al-Islam (RibaFree Banking in Islam).

The rationale for writing this unique book was a request from the government of Kuwait. At that time, Kuwait's rulers had realized that the money people were receiving from profits made by the oil industry was being invested for interest in conventional banks and financial institutions. Being Muslim, these investors wanted to find a way to avoid paying or earning riba. Martyr Sadr was therefore commissioned by the government of Kuwait to assess how the country's oil wealth could be managed in keeping with Islamic principles. This led to the initial major work on Islamic banking that still forms the theoretical basis for riba-free banking (Askari et al., 2009, p. 94). In this book, the shariah-compliant method that an Islamic bank can use to receive and mobilize deposits is presented and the jurisprudential modes that Islamic banks can make use of to provide financing facilities to customers are discussed. In other words, Martyr Sadr tries his best to eliminate riba from both sides of banking activity, in consideration of the intermediatory nature of all financial institutions (Sadr, 1970, p. 45).

This theoretical innovation was put into practice in Iran after the Islamic Revolution of 1979, and thereafter its banking system changed dramatically. The paying and receiving of riba, outstanding debts, the asset devaluation of private banks, and a slump in banking activities formed the main challenges to the banking system at the time of revolution. To preserve the rights of depositors and national assets, to safeguard deposits and savings, and to strengthen the flow of shariahcompliant finance to industry, the Iranian government nationalized the country's banks. Simultaneously, several banks were merged and six commercial banks (Refah, Melli, Saderat, Tejarat, Mellat and Sepah) and three specialized banks (Agriculture, Housing, and Industry and Mining) emerged out of the 37 banks in operation in Iran at that time (Gudarzi Farahani \& Sadr, 2012, p. 15).

The Iranian government then ratified the RFBA in 1983, mostly based on the theoretical background developed by Martyr Sadr. Based on justice and riba-free banking operations, the new law aimed to solidify Iran's credit and monetary system so that the value of money could be preserved, payments could be balanced, and commercial transactions could be facilitated via the proper circulation of money and credit.

By the early 198 0s, a wave of modern technologies was beginning to transform the face of the Iranian banking system. In 1993, a comprehensive banking automation scheme was officially introduced to optimize banking activities in the field of informatics. In 2000, following the third Five-Year Development Plan, private banking law was passed which saw the emergence of numerous banks 
and financial institutions, including Parsian, Saman, Eqtesad-e-Novin, Pasargad, Karafarin, Sarmayeh, Day, Sina and Ayandeh (Nili, 2014, p. 11)².

Although the Iranian model for conducting Islamic banking has some important similarities with those of other countries, there are a few important differences that need to be highlighted. Some of these dissimilarities include those identified by Musavian and Meisamy (2018, p. 233):

1. The Iranian shariah-compliant banking model is conducted within a countrywide system of more than 24,000 banking branches and without the presence of a conventional banking sector. In this regard, it differs significantly from other Islamic countries (such as Malaysia) in which a dual-banking system is practised.

2. The Iranian model is based on the Shia Fiqh school of thought, whereas, in most of the other Islamic countries, Sunni schools of jurisprudence set the rules applied.

3. The Islamic banking model of Iran is backed by an independent act that was ratified in 1983 and has been in force ever since. Such a reference act is absent in most other Islamic countries.

4. The Islamic banking model of Iran uses wakalah in the mobilization of resources, which includes term investment deposits. Most Islamic countries, however, use contracts such as mudarabah and wadiah instead.

5. Bai-al-dain (debt sale), which is not common in other Islamic countries except Malaysia, is permitted in the Iranian Islamic banking model.

6. Based on Shia Fiqh, mudarabah is limited to the buying and selling of commodities; other countries do not follow this restriction.

7. Islamic banks in other countries pay part of their revenues as zakat, which is reflected in their balance sheets. Such a practice is not common in Iran.

8. One single shariah board within the Central Bank of Iran serves the entire banking system, whereas in other Islamic countries each bank has its own shariah board.

9. The Iranian riba-free banking system is allowed to impose a certain level of fines, calculated as a percentage of bank revenues, for the delayed repayment of loans. Most Islamic banks in other countries do not receive such fines or allocate them to benevolent charitable activities separate from bank resources.

10. In the Iranian banking system, the profit rate of Islamic contracts (used by banks for resource allocation) is decreed by the government, while in other countries governments refuse to intervene.

11. Approximately 6,000 private qard-al-hasan funds, founded by benevolent individuals/organizations, are present in the Iranian financial market and offer small riba-free loans across an extensive social network to those in need. Other Islamic countries lack such institutions.

12. In Iran, sukuk are is used for monetary policy as well as the financing of both public and private sector needs. The majority of other Islamic countries (except Sudan) use these instruments only for project financing.

2 It should be noted that many Iranian private banks are not in fact genuinely private, with the government and/or non-governmental public entities playing important roles in their ownership and management. 
13. Islamic accounting and auditing standards are not commonly practised across the whole Iranian system, and only Basel standards are observed. In contrast, in other Islamic countries, the Accounting and Auditing Organization for Islamic Financial Institutions (AAOIFI) standards are practised in a way which differs from conventional models of banking standards .

\subsection{Previous Studies}

Existing literature about the practice and challenges of the Islamic banking system in Iran is very rare. Some of the works which do exist are evaluated in this section.

Ashraf and Alizadeh Giashi (2011) evaluate the progress of and challenges to the Iranian Islamic banking system. They show that at the time of writing it was facing a difficult time in the wake of economic sanctions against Iran . Compounding this, Islamic banks may face future problems since they do not follow the same rules and regulations in the realm of Islamic banking to the rest of the world. One such problem entails banks seeking maximum profits without exposing themselves to risk to the detriment of other parts of the contracts upon which all risk is imposed.

Gudarzi Farahani and Sadr (2012) examine the short-run and long-run relationships between Islamic banking development and economic growth in the cases of Iran and Indonesia. Their paper also addresses some of the issues and challenges that Islamic banking faces in Iran. Their results show that although there are some challenges in conducting Islamic banking in practice, there is a significant positive relationship between Islamic financial development and economic growth.

Nili (2014) evaluates the history and current practices of the Iranian currency and capital markets in conducting shariah-compliant business. In this report, some of the challenges of the Iranian Islamic banking system are briefly discussed and itemized based on the author's experience. These challenges include sole reliance on jurisprudence, insufficient attention to low-income groups, and fake activities.

Zamil (2014) examines the theoretical and practical aspects of the problems and challenges facing Islamic banking and finance in Malaysia. The study focuses on four main issues: legal and regulatory framework, shariah compliance, management, and accounting. To achieve its objectives, the study uses semistructured interviews to survey different groups of respondents involved in the operation of Islamic banking and finance. The major problems and challenges emerging from the interview findings of the study are as follows: the influence of the dual-banking environment; lack of support from the regulatory framework in relation to products and services; shariah non-compliance; operations and management; lack of expertise in human capital; lack of accountability; and lack of influence of accounting practices and auditing.

Parveen, Langari Zadeh and MuzakkirSyed (2015) discuss the evolution of Islamic banking in Iran with special emphasis on its prospects and problems. The results of their paper show that the government of Iran played a primary role in converting conventional banking into Islamic banking after the 1979 revolution. Also, far from achieving the three-fold objectives of the RFBA, they identify that the sector is plagued by slow growth, a large portfolio of non-performing assets, and a narrow range of products and services. 
Shaukat (2017) evaluates the regulatory challenges faced by Islamic banks from the perspective of Islamic bankers in Pakistan. The results show that based on Islamic bankers' views the most important regulatory challenges in Pakistan include licensing and authorization, shariah supervision, institutional harmonization, and information disclosure. In addition, the findings demonstrate no statistically significant difference in bankers' perceptions concerning regulatory challenges to Islamic banking based on their gender or on the nature of the bank they work for. However, the participants' qualifications, professional experience, and career levels appeared to be correlative of Islamic bankers' perceptions regarding regulatory challenges.

As can be seen, although some challenges facing the Iranian banking system have been evaluated in previous research, the literature lacks comprehensive assessment and expert ranking of the specific challenges to implementing Islamic banking in Iran. Hence, the current paper aims to enhance awareness about the challenges facing Islamic banking practice in Iran and to build upon the existing body of literature.

\subsection{Islamic Banking in Iran}

After the 1979 Islamic Revolution, the conventional (interest-based) banking that prevailing in the Iranian financial markets before the revolution could not continue, and a provision was included in the government's budget law of 1981 wherein academicians, experts from the Central Bank and the Ministry of Finance, and a Fiqh scholar collaborated on the draft bill for riba-free banking. After some modifications, the RFBA was ratified by parliament in September 1983. Subsequently, related guidelines, directives, and circulars were written and approved. Since then, all banks and credit institutions in Iran have adapted Islamic rules and are supposed to act as shariah-compliant businesses.

The RFBA, which has been in place since 1983, consists of four chapters: objectives and duties of the banking system; mobilization of financial resources; banking facilities; and central banking and monetary policy. The first two chapters are explained below (Central Bank of Iran, 2008, pp. 12-14).

\section{A) Objectives}

According to Article 1 of the RFBA, the objectives of the banking system are itemized as follows:

1. Establishment of a monetary and credit system based on rightness and justice (as delineated by Islamic jurisprudence) to regulate the sound circulation of money and credit to enhance the health and growth of the country's economy.

2. The banking system to avail itself of monetary and credit mechanisms to enable it to engage in activities conducive to the attainment of the economic goals, policies, and plans of the government of the Islamic Republic.

3. The creation of necessary facilities for the extension of cooperation and qardal-hasan among the general public through the attraction and absorption of surplus funds, reserves, and savings and deposits, and the mobilization thereof in the provision of conditions and opportunities for gainful employment and investments, as stipulated in Clauses 2 and 9, Article 43 of the Constitution. 


\section{B) Duties}

Duties of the banking system based on Article 2 of the RFBA are itemized as follows:

1. Issuance of notes and coins as legal tender in conformity with laws and regulations.

2. Regulating, controlling, and guidance of the circulation of money and credit, in accordance with laws and regulations.

3. Performance of all banking operations in foreign exchange and local currency, and undertaking or guaranteeing the foreign exchange payments of the government, according to laws and regulations.

4. Supervision of transactions in gold and foreign exchange and the inflow and outflow of domestic and foreign currencies, and the formulation of regulations governing thereof, following laws and regulations.

5. Performance of operations relating to securities and other paper assets according to laws and regulations.

6. Conducting monetary and credit policies, in accordance with laws and regulations.

7. Performing banking operations related to those parts of the approved economic plans which are to be conducted through the monetary and credit system.

8. Opening of various qard-al-hasan (current and savings) accounts and long-term investment deposits and issuance of relevant certificates, as required by laws and regulations.

9. Granting of riba-free loans and credit in accordance with laws and regulations.

10. Granting loans and credits and provision of other banking services to legallyestablished cooperatives, for the realization of the provisions of Clause 2, Article 43 of the Constitution.

As can be seen, Article 2 of the RFBA has, since its enactment, obligated the banking system with respect to all tasks and duties being practised by the central and commercial banks of other countries. The banking system is therefore provided with the required instruments and mechanisms by the stipulations of Chapter II of the act.

\section{C) Resources Mobilization}

Articles 3 to 6 of Chapter II of the RFBA describe the allowed modes of mobilization of resources, as follows:

ARTICLE 3: Banks are authorized to accept deposits under each of the following titles:

- Qard-al-hasan deposits in current and saving accounts

- Term investment deposits

NOTE: Term investment deposits - for the utilization of which the bank works as a wakil, i.e. attorney - shall be used in joint ventures, mudarabah, hirepurchases, instalment transactions, muzaraah, musaqat, direct investments, forward dealings, and joaalah modes of finance.

Based on this article, and in contrast to other Muslim countries, the only contract used for fund mobilization of non-qard-al-hasan deposits is wakalah. 
ARTICLE 4: Banks are obliged to repay the principals of qard-al-hasan (saving and current) deposits and may undertake and/or ensure the principals of term investment deposits.

ARTICLE 5: Based on the signed agreement, proceeds derived from activities stipulated in the note to Article 3 shall be apportioned in proportion to the term and the amounts of investment deposits and bank resources.

ARTICLE 6: In order to attract and mobilize deposits, banks may, through promotional methods, give the following rewards to depositors:

- Non-fixed bonuses in cash or in kind to qard-al-hasan deposits

- Exemption from or discounts thereto, in payment of commissions and/or fees

- Priority to depositors in the use of banking facilities as specified in Chapter III.

Based on Article 6, most Iranian banks and credit institutions offer awards for qard-al-hasan deposits, though such a process is not binding.

\subsection{The Challenges Facing Shariah - Compliant Banking in Iran}

With more than three decades of history, riba-free banking in Iran has made substantial achievements (Hassani, 2010, p. 22). However, there exist important shortcomings and challenges which are discussed widely in the related literature. By systematically reviewing this literature, the most important challenges facing the Iranian Islamic banking system can be itemized (and discussed briefly) as follows:

\section{A) Theoretical Challenge}

Given the fact that Islamic banking, as a field of study, is new in comparison to conventional banking, it presents some theoretical challenges; for example, the exact meaning of riba and ways to solve disagreements between Islamic scholars in regard to riba are main theoretical challenges within Islamic banking.

The permissibility of money creation in an Islamic banking system, the role of money in the new monetary system, the relationship between contracts based on the sharing of profit and loss (such as musharakah) and trade-based contracts (such as murabaha) and so on, form some of the other theoretical challenges to Islamic banking in Iran (Toutounchian, 2013, p. 121).

\section{B) Governmental Attitudes towards Islamic Banking}

Islamic banking in Iran can be considered as a governmental initiative designed and developed within a top-down framework. Hence, unlike many other Islamic banking systems prevailing in other countries (such as Malaysia), the private sector is not active enough in developing shariah-compliant banking services in Iran because the governmental view dominates. This may be the reason and rationale for the presence of the public sector even in the management of private or privatized banks in Iran. 


\section{C) Lack of Competition}

Unlike many Islamic countries that make use of a dual-banking system, the Iranian Islamic banking model has been applied exclusively and nationwide since its introduction. Thus all banking branches in the country (almost 24,000) are should be shariah compliant, leaving no room for conventional banking.

This system may lack of competition, thereby reducing the incentives for the Islamic banks to work at product innovation and develop better products for consumers (Hassan \& Lewis, 2007, p. 15).

\section{D) Lack of a Legitimate Solution for Dealing with Delayed Payments and Rolling Over of Due Debts}

Based on shariah rulings, an Islamic bank cannot impose fees for delayed payments or rolled-over (renewed or rescheduled) loans, as is practised in conventional banks. Given this, it seems that the repayment of debts or the renewing of due loans is another challenge to the Iranian banking system for which no economic solution consistent with Islamic jurisprudence has yet been found. The legitimate way of imposing fines for delays in repayment has been a matter of debate since the Islamic Revolution.

\section{E) Requesting Collateral Even in Musharakah Contracts}

Because credit ratings are not a prevailing issue in the Iranian banking system, most of the banks request collateral from customers in the form of a property or other asset that a borrower offers as a means of securing the loan taken. If the borrower stops making the promised loan payments, the bank can seize the collateral to recoup its losses.

Usually, loans that are secured by collateral have lower rates, given that collateral offers some security to the bank should the borrower fail to pay back the loan. However, this is not the case in the Iranian banking system, in which collateral does not have anything to do with the rate charged . Finally, it should be noted that based on international Islamic banking standards it is not possible to request collateral in musharakah contracts (AAOIFI, 2017, p. 321).

\section{F) Not Revising the Law (RFBA)}

Unfortunately, the RFBA, which has been in place since 1983, is yet to be revised. Hence, this very important law does not include or account for new developments in the field of Islamic banking and finance. In addition, given its age, it cannot provide for the contemporary financial needs of the public (Mojtahed \& Hassanzadeh, 2009, p. 31).

\section{G) Lack of Shariah Supervision}

Shariah supervision in Islamic banks (or financial institutions) is one of the most important governance mechanisms for ensuring compliance with shariah law. Therefore, it is clear that the shariah board's role is to help ensure that the Islamic 
banks' business models, instruments, contracts, policies, and investments follow the dictates of shariah law (AAOIFI, 2017, p. 205).

Unfortunately, shariah supervision is not properly implemented or conducted in the Iranian banking system. In other words, although there are more than 24,000 Islamic banking branches in the county, they are not specifically supervised to ensure that all their activities are shariah compliant.

\section{METHODOLOGY}

\subsection{Data}

It seems there is agreement in the Delphi technique literature that the first and the most important issue in using Delphi is the correct formation of the expert panel. In fact, adequate stakeholder representation is a requisite for the success of the Delphi technique. Furthermore, the literature suggests a panel comprising of 8 members as the minimum, 16 members as the average and 80 members as the maximum (Hsu \& Sandford, 2007, p. 17).

In this paper, 32 Iranian Islamic banking experts were selected for interview (based on availability), chosen to contribute to the study through their in-depth knowledge and experience. Hallowell and Gambatese (2009) emphasize the importance of expertise in the respondent group. Thus, careful effort was put in to identifying and contacting highly educated and experienced panellists.

\subsection{Conceptual Framework}

Previous studies have shown that the Delphi technique is a commonly used model for determining experts' perceptions about the challenges facing a system and ranking them based on priority (see, among others, Franklin \& Hart, 2007; Hsu \& Sandford, 2007; Mayfield, Wingenbach, \& Chalmers, 2005)

However, there are some important requirements for the use of Delphi in qualitative research, given that it is mainly based on the individuals' judgments and opinions. These requirements include the object of the research being complex, multidimensional, and interdisciplinary, the need for expert decisions, anonymity in data collection, imperfect knowledge, experienced and capable experts, dispersion of experts, and no time limitation (Herumurti, 2019, p. 6).

The main question of the current research is: 'what are the challenges of Islamic banking in Iran?' This issue is complex, multidimensional, and interdisciplinary and there is a need to gather professionals' views about it. It therefore seems that the Delphi technique is one of the best approaches for answering our research question and can be used to determine and rank the challenges facing the Islamic banking system in Iran.

The proposed conceptual framework of the research is presented in Figure 1. It is clear that all the 10 challenges described previously can be considered from strategic-operational as well as internal-external points of view. Issues such as governmental attitudes towards Islamic banking, lack of competition, not revising the law (RFBA), theoretical challenges, and lack of research and education can be considered strategic shortcomings of the Iranian Islamic banking system. On the other hand, problems such as lack of shariah supervision, lack of accounting and 
auditing standards, lack of a legitimate solution for delayed payments and rollingover, paying 'on-account monthly profit' to depositors, and requesting collateral even in musharakah contracts can be considered as being operational challenges.

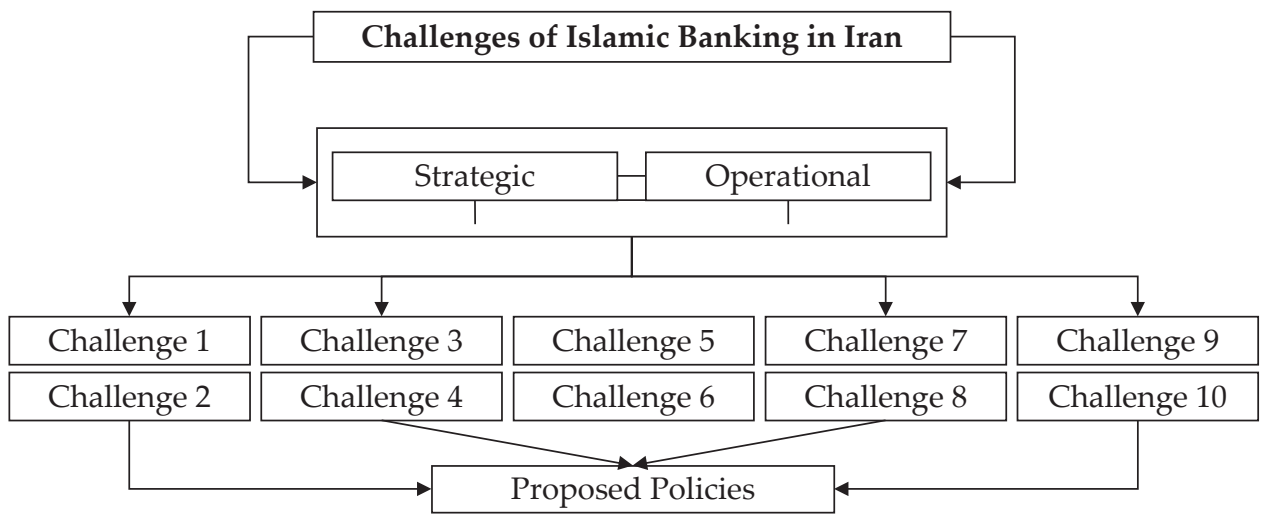

Source: Authors

Figure 1.

Proposed Conceptual Framework

\subsection{Method}

Norman Dalkey and Olaf Helmer of the Rand Corporation (a research and development organization) originally conceived the Delphi method in the late 1950s. The technique allows a group of individuals as a whole to deal with a complex problem. The method involves the flow of knowledge from one round of questioning to the next and assimilates the view of the experts and channels it towards a consensus (Dalkey \& Helmer, 1963, p. 21; Linstone \& Turoff, 1975, p. 33).

Delphi is effectively used to collect and synthesize expert judgments; however, its real value lies in the ideas it generates. The Delphi method is also used for the 'derivation of probable challenges and shortcomings' (Nowack, Endrikat, \& Guenther, 2011, p. 15).

This technique is characterized by anonymity, iteration, controlled feedback, group response, and expert participation. The strength of Delphi rounds is that experts can voice their opinions without the negatives of face-to-face discussion, reducing dominance and bandwagon effects and enabling positive criticism. To identify the challenges facing Islamic banking in Iran, a three-phase Delphi study is undertaken (Gracht, 2012, p. 13).

\subsection{Research Steps}

Previously, the most important challenges to the Islamic banking system in Iran have been presented based on the extant literature. In this section, these challenges are evaluated and ranked based on experts' views using the Delphi method of consensus building. The steps used in the Delphi method in this research are depicted in Figure 2 and can be explained as follows: in the first round of the 
Delphi technique, an open-ended questionnaire (based on a Likert scale) was given to the panel members. This questionnaire included the seven above-mentioned challenges as derived from the literature. Panellists were asked to add their own challenges to the questionnaire, should they believe there are other important shortcomings that had not been presented.

In the Likert scale, an intensity degree is associated with the level of agreement or disagreement: strongly disagree (1), disagree (2), neither agree nor disagree (3), agree (4), and strongly agree (5).

To analyse the completed questionnaires, the binomial test in the SPSS 16 software was used. All the panellists were divided into two groups. The first group consisted of those who chose 'strongly agree' and 'agree' (success), while the second group consisted of those who chose 'strongly disagree', 'disagree', and 'neither agree nor disagree' (failure).

In the second round of the Delphi process, a closed-ended questionnaire (again based on a Likert scale) was administered to the experts. This questionnaire included 10 challenges, the original seven plus three new shortcomings derived from the first round. After reaching consensus in the second round, the ranking of challenges based on priority is conducted in the third round of the Delphi technique.

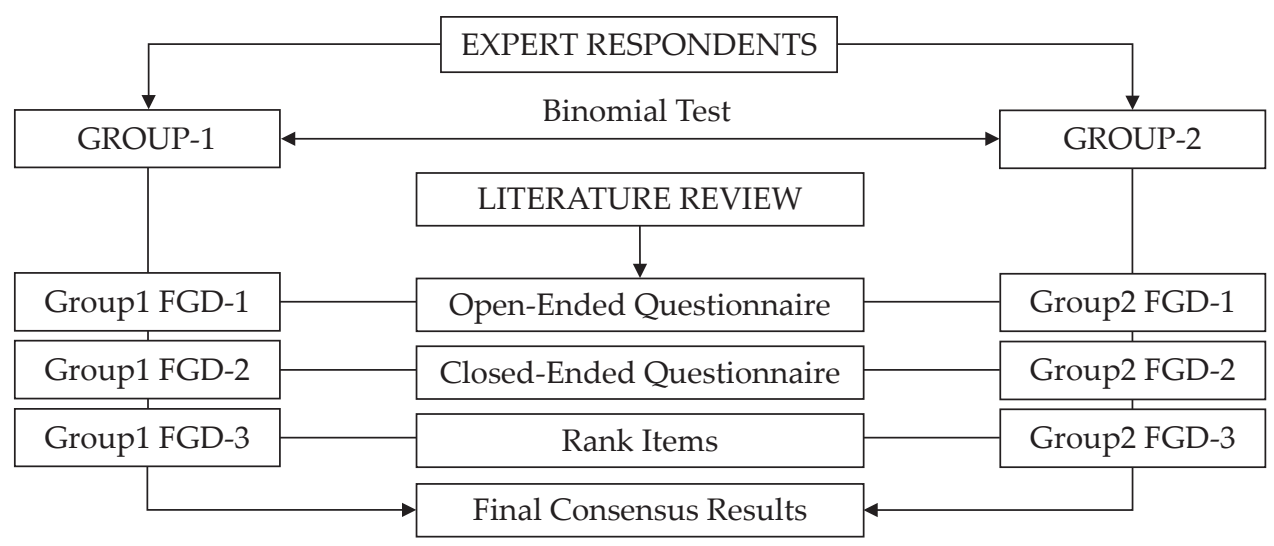

Source: Authors

Figure 2.

Steps in the Delphi Research

\section{RESULTS AND ANALYSIS}

\subsection{Results}

The results of the three rounds of Delphi are depicted in Tables 1, 2, 3, and 4. Table 1 displays the results of the Delphi first round. As illustrated, the significance level of all seven challenges is within a range that shows the rejection of the null hypothesis. Therefore, the experts confirm their agreement with all the challenges to the Iranian Islamic banking system that were derived from the literature. 
In addition, the results show that in the first round, the panel members pointed to three new challenges to the Islamic banking system in Iran:

- Paying on-account monthly profit to depositors (not calculating the exact profits and not distributing the difference between depositors).

- Lack of accounting and auditing standards (neither AAOIFI nor the Islamic Financial Service Board [IFSB] is implemented in the Iranian banking system ${ }^{3}$ ).

- Little research and education in the field of Islamic banking and finance.

Table 1.

Results of Delphi First Round

\begin{tabular}{llccc}
\hline No. & \multicolumn{1}{c}{ Challenge } & $\begin{array}{c}\text { Significance } \\
\text { Level }\end{array}$ & $\begin{array}{c}\text { Success } \\
\text { Probability }\end{array}$ & $\begin{array}{c}\text { Reject/Accept the } \\
\text { Hypothesis }\end{array}$ \\
\hline 1 & Theoretical challenge & 0.000 & 95 & rejected \\
2 & $\begin{array}{l}\text { Governmental attitude towards } \\
\text { Islamic banking }\end{array}$ & 0.000 & 87 & rejected \\
3 & $\begin{array}{l}\text { Lack of competition } \\
\text { Lack of a legitimate solution for }\end{array}$ & 0.018 & 67 & rejected \\
4 & $\begin{array}{l}\text { delayed payments and rolling- } \\
\text { over }\end{array}$ & 0.036 & 65 & rejected \\
5 & $\begin{array}{l}\text { Requesting collateral even in } \\
\text { musharakah contracts }\end{array}$ & 0.088 & 64 & rejected \\
7 & Not revising the law (RFBA) & 0.088 & 64 & rejected \\
7 & Lack of shariah supervision & 0.089 & 63 & rejected \\
\hline
\end{tabular}

* Note: $95 \%$ confidence level

Table 2 presents the results of the Delphi second round. As can be seen, the significance level of all 10 challenges indicates that the null hypotheses are rejected. Thus, we can conclude that based on the experts' views, all of the 10 challenges to the Iranian Islamic banking system are confirmed.

The results of the second round of Delphi clearly show that the panellists confirmed all 10 challenges of the Iranian Islamic banking system. This in turn demonstrates consensus, which is a critical issue in conducting the Delphi technique.

3 The Accounting and Auditing Organization for Islamic Financial Institutions (AAOIFI) and the Islamic Financial Services Board (IFSB) are two well-known international standard-setting organizations in the field of Islamic banking and finance. 
Table 2.

Results of Delphi Second Round

\begin{tabular}{|c|c|c|c|c|}
\hline No & Challenge & $\begin{array}{c}\text { Significance } \\
\text { Level }\end{array}$ & $\begin{array}{c}\text { Success } \\
\text { Probability }\end{array}$ & $\begin{array}{l}\text { Reject/Accept the } \\
\text { Hypothesis }\end{array}$ \\
\hline 1 & Theoretical challenge & 0.000 & 93 & rejected \\
\hline 2 & $\begin{array}{l}\text { Governmental attitude towards } \\
\text { Islamic banking }\end{array}$ & 0.000 & 88 & rejected \\
\hline 3 & Lack of competition & 0.018 & 69 & rejected \\
\hline 4 & $\begin{array}{l}\text { Lack of a legitimate solution for } \\
\text { delayed payments and rolling-over }\end{array}$ & 0.036 & 64 & rejected \\
\hline 5 & $\begin{array}{l}\text { Requesting collateral even in } \\
\text { musharakah contracts }\end{array}$ & 0.088 & 63 & rejected \\
\hline 6 & Not revising the law (RFBA) & 0.088 & 63 & rejected \\
\hline 7 & Lack of shariah supervision & 0.089 & 62 & rejected \\
\hline 8 & $\begin{array}{l}\text { Paying on-account monthly profit to } \\
\text { depositors }\end{array}$ & 0.089 & 62 & rejected \\
\hline 9 & $\begin{array}{l}\text { Lack of accounting and auditing } \\
\text { standards }\end{array}$ & 0.037 & 64 & rejected \\
\hline 10 & Little research and education & 0.087 & 63 & rejected \\
\hline
\end{tabular}

* Note: $95 \%$ confidence level

Having confirmed all the challenges, the third round of Delphi concerned the ranking of challenges. For this, all 10 confirmed challenges were presented to the panellists to rank according to importance. To analyse the third round completed questionnaires, the Friedman test procedure (analysis of variance by ranks) was used. In this test, the null hypothesis was that there is no difference between the 10 challenges; hence, all of them are equally important. The results of this test are presented in Table 3.

Table 3.

Results of the Friedman Test

\begin{tabular}{lcccc}
\hline $\begin{array}{l}\text { The Calculated } \\
\text { Statistic }\end{array}$ & $\begin{array}{c}\text { Degree of } \\
\text { Freedom }\end{array}$ & $\begin{array}{c}\text { Significance } \\
\text { Level }\end{array}$ & $\begin{array}{c}\text { Confidence } \\
\text { Level }\end{array}$ & $\begin{array}{c}\text { Reject/Accept the } \\
\text { Hypothesis }\end{array}$ \\
\hline 78.66 & 10 & 0.000 & $95 \%$ & rejected \\
\hline
\end{tabular}

As shown, the null hypothesis is rejected. This means that based on the panellists' views, the importance of the Iranian Islamic banking challenges is not equal and there are differences between them. The ranking of challenges is provided in Table 4. 
Table 4.

Ranking of Iranian Islamic Banking Challenges based on Experts' Views

\begin{tabular}{lc}
\hline No. & Challenge \\
\hline 1 & Governmental attitude towards Islamic banking \\
2 & Lack of competition \\
3 & Not revising the law (RFBA) \\
4 & Lack of shariah supervision \\
5 & Lack of accounting and auditing standards \\
6 & Theoretical challenge \\
7 & Little research and education \\
8 & Lack of a legitimate solution for delayed payments and rolling-over \\
9 & Paying on-account monthly profit to depositors \\
10 & Requesting collateral even in musharakah contracts \\
\hline
\end{tabular}

\subsection{Analysis}

The main results and contributions of this research are presented in Table 4 . Based on our findings, the first two most important challenges facing the Islamic banking system in Iran relate to the role of government. In fact, the Islamic banking system in Iran is a governmental initiative that is developed in a top-down context. This is contrary to the worldwide experience of Islamic banking systems (in countries such as Malaysia, Indonesia, Bahrain, the United Arab Emirates, and so on) where dual banking is practised. This finding is in accordance with Nili (2014) and Parveen et al. (2015) and indicates the importance of competition in the development of Islamic banking. The initial policy recommendation to solve this challenge could be the privatization of the banking industry so that the private sector becomes an active part of the Iranian banking system.

Not revising the law (the RFBA) is another very important challenge to the Iranian banking system. The law has not been revised since 1983 and hence does not include subsequent developments in the fields of Islamic banking and finance. The policy recommendation related to this issue is simply to revise the law by considering the Islamic banking regulation initiatives in other Islamic countries, such as Malaysia.

Based on the findings, lack of shariah supervision and lack of accounting and auditing standards form the next two important challenges to the riba-free banking system in Iran. In fact, supervising shariah compliance in Islamic bank operations is not conducted robustly and no shariah accounting and auditing standards are mandatory for Iranian banks and financial institutions. The policy recommendation here could be the enforced establishment of shariah boards in all Iranian banks and, in addition, enforcing application of AAOIFI standards.

The results show that theoretical challenges and lack of research and education are not among the first five most important challenges to the Islamic banking system of Iran. This finding is contrary to previous research, such as Siddiqi (2004) and Al-Jarhi (2002), that focuses on the importance of theoretical challenges in the development of Islamic banking systems. The policy recommendation about these issues could be collaboration between the banking system and the universities and research institutes, enabling the real challenges to Iranian banks in practice to be considered as research topics for Islamic banking academics. 
Lack of a solution for delayed payments, the paying of on-account profit to depositors, and the requesting of collateral in musharakah contracts are the final challenges to the Iranian Islamic banking system in Iran. The policy recommendations related to delayed payment could be to consider these funds for charitable use, as is the practice of Islamic banks in other countries where delayed payment penalties are collected but are then disposed of for charitable purposes. The challenge of on-account profit could be solved by differentiating the asset pools of musharakah and trade-based Islamic contracts. In this way, those depositors who invest in the musharakah asset pool of an Islamic bank will be participating in the profit of the bank and those who choose the trade-based asset pool are granted a fixed and pre-determined rate of profit. This profit is not riba because the funds related to this asset pool are used by the Islamic banks for tradebased contracts such as murabaha. Finally, Islamic banks should be banned from requesting collateral in musharakah contracts because this is contrary to the nature of musharakah.

\section{CONCLUSIONS AND RECOMMENDATIONS}

\subsection{Conclusions}

This study identifies the various challenges to shariah-compliant banking in Iran and suggests a prioritized list of challenges facing the industry created using a three-round Delphi method. The results show that the Iranian model of Islamic banking, despite its long history, faces some significant challenges. The most important are governmental attitude towards Islamic banking, lack of competition, not revising the law (RFBA), lack of shariah supervision, lack of accounting and auditing standards, theoretical challenges, limited research and education in Islamic banking, lack of a legitimate solution for delayed payments and rolling-over of debts, paying on-account monthly profit to depositors, and, finally, requesting collateral even in musharakah contracts.

\subsection{Recommendations}

Based on the findings, the study suggests the development of the following policies by regulators, practitioners and areas of interest for future researchers:

1. The Iranian government and non-governmental public entities should exit the banking system and let the genuinely private Islamic banks compete with others in a sound and regulated way (similarly to other Islamic countries such as Malaysia).

2. The Iranian RFBA is outdated and cannot meet the new requirements of the banking system. It is therefore of the highest importance that the law is revised immediately by the Iranian parliament (The Islamic Consultative Assembly), taking into consideration the newest developments in the theory and practice of Islamic banking worldwide (e.g. making use of sukuk in the banking system, using Islamic interbank instruments, and so on).

3. In the Iranian Islamic banking business, shariah supervision is improperly regulated and implemented, given that only the shariah board in place is that of the central bank. The practitioners of the Islamic banking industry in Iran 
need to understand the necessity of shariah boards, in recognition of the fact that compliance with shariah law is the underlying rationale for the existence of Islamic finance. Hence, it is recommended that all Iranian banks establish shariah supervisory boards to advise them on whether their products comply with shariah and to ensure that their operations and activities comply with Islamic principles. This may help the banks to internally supervise their contracts and activities based on shariah rules.

4. Iran's banking system is suffering from a lack of accounting and auditing standards in conducting Islamic contracts. Hence, it is important for the banking system (including the central bank and commercial banks) to develop relevant standards for conducting Islamic banking, making use of international experience in this regard (e.g. AAOIFI standards).

5. It is important for the reputation of the banking system of Iran that a shariahcompliant solution for the issue of delayed payments and rolling-over be considered, using other Islamic banks' experiences as well as international standards. An initial solution for this challenge could be disposing of the delayed payment funds for charitable purposes, as is practised in some Islamic countries.

6. Iranian Islamic banking stakeholders have so far failed to maintain constructive cooperation with other Islamic countries in the field of Islamic banking. Hence, the international community knows little about the theoretical foundations and practice of riba-free banking in Iran. Deeper and wider cooperation in scientific and administrative fields is of crucial importance, for example, by opening branches of foreign Islamic banks in Iran to enhance cooperation.

7. There is a need for all Iranian institutions related to research and education about the banking system to pay the greatest attention to the role of research and development in Islamic banking and finance. This will improve practice within the system in the long run. To be specific, further in-depth research is needed about all the 10 challenges emphasized in this research based on the experts' views. In addition, close collaboration between the banking system and the universities and research institutes can be emphasized.

8. The usage of musharakah contracts in the Iranian banking system is much more prevalent than in other Islamic countries. However, in reality these contracts are drawn up in fake and inappropriate ways and hence present a serious risk of riba. It can be recommended that Iranian banks make use of trade-based contracts (especially murabaha) which provide a simple shariahcompliant mode of financing. Unlike musharakah contracts that need a great deal of supervision and administration, trade-based contracts can be more easily conducted.

9. Last but not least is the idea of differentiating musharakah and trade-based asset pools for accepting deposits in Islamic banks and to this end it could be suggested that Iranian banks generally accept two kinds of deposits. The first is related to the musharakah asset pool and depositors would be participating in final profit along with the banks, while in the second, trade-based depositors would be offered a smooth but fixed rate of profit.

This study has its limitations: in particular, it is purely an initial exploratory study using the Delphi method, and so further studies are needed. For example, 
various qualitative methods such as analytic network process (ANP), strategic assumption surfacing and testing (SAST) and structural equation modelling (SEM) could all be used in future research. Moreover, further studies using various quantitative methods and using time-series and panel data are also needed to empirically examine the real condition of Islamic banking in Iran.

\section{REFERENCES}

AAOIFI. (2017). Accounting, Auditing, and Governance Standards for Islamic Financial Institutions. Bahrain: Accounting and Auditing Organization for Islamic Financial Institutions.

Al-Jarhi, M. A. (2002). Islamic Finance: An Efficient and Equitable Option. Jeddah: Islamic Research and Training Institute, Islamic Development Bank.

Ashraf, H., \& Alizadeh Giashi, A. (2011). Islamic Banking in Iran: Progress and challenges, Kuwait Chapter of Arabian Journal of Business and Management Review, 3(1), 14-32.

Askari, H., Iqbal, Z., \& Mirakhor, A. (2009). Globalization and Islamic finance: Convergence, Prospects, and Challenges. Washington: Wiley Finance.

Central Bank of Iran. (2008). the Law for Usury (Interest) Free Banking. Tehran: CBI publication.

Central Bank of Iran. (2017). Annual Report. Tehran: CBI publication.

Dalkey, N., \& Helmer, O. (1963). An Experimental Application of the Delphi Method to the Use of Experts. Management Science, 9(1), 458-467.

Franklin, K., \& Hart, J. (2007). Idea Generation and Exploration: Benefits and Limitations of the Policy Delphi Research Method. Innovative Higher Education, 31(4), 23-44.

Gracht, H. (2012). Consensus Measurement in Delphi Studies. Technological Forecasting and Social Change, 79(2), 12-30.

Gudarzi Farahani, Y. \& Sadr, S. (2012). Analysis of the Islamic Bank's Financing and Economic Growth: Case Study of Iran and Indonesia. Journal of Economic Cooperation and Development, 33(3), 98-110.

Hallowell, M., \& Gambatese, J. (2009). Qualitative Research: Application of the Delphi Method to CEM Research. Journal of Construction Engineering and Management, 136(2), 45-67.

Hassan, K. \& Lewis, M. K. (2007). Handbook of Islamic Banking. Cambridge: Center for Middle Eastern Studies.

Hassani, M. (2010). Islamic Banking and Monetary Policy: Experience of Iran. International Review of Business Research Papers, 6(1), 44-66.

Herumurti, A. (2019). Policy Formulation Model Based On Delphi Engineering. Public Policy and Administration Research, 9(7), 17-35.

Hsu, C., \& Sandford, B. (1998). The Delphi Technique: Making Sense of Consensus. Practical Assessment, Research, and Evaluation, 14(3), 54-89.

Hsu, C., \& Sandford, B. (2007). The Delphi Technique: Making Sense of Consensus. Practical Assessment Research and Evaluation, 12(2), 67-89.

Iqbal, Z., \& Mirakhor, A. (2011). An Introduction to Islamic Finance: Theory and Practice. Washington: Wiley Finance. 
Linstone, H., \& Turoff, M. (1975). The Delphi Method: Techniques and Applications. Boston: Addison-Wesley Publishing Company.

Mayfield, C., Wingenbach, G., \& Chalmers, D. (2005). Assessing Stakeholder Needs: Delphi Meets the Internet. Journal of Extension, 43(3), 4-25.

Mojtahed, A., \& Hassanzadeh, A. (2009). A Survey on Islamic Banking and Finance in Iran. Tehran: Monetary and Banking Research Institute (in Persian).

Musavian, A., \& Meisamy, H. (2018). Islamic Banking (1): Theory and Practice (6th ed.), Tehran: The Monetary and Banking Research Institute (in Persian).

Nili, F. (2014). Iran: Islamic Banking and Finance. In S. Thiagaraja, A. Morgan, A. Tebbutt, \& G. Chan (Eds.), The Islamic Finance Handbook: A Practitioner's Guide to the Global Markets (pp. 175-212). Singapore: John Wiley and Sons.

Nowack, M., Endrikat, J., \& Guenther, E. (2011). Review of Delphi-Based Scenario Studies: Quality and Design Considerations. Technological Forecasting and Social Change, 78(4), 1-24.

Parveen, T., Langari Zadeh, E., \& MuzakkirSyed, A. (2015). Evolution of Islamic Banking in Iran: Prospects and Problems. IOSR Journal of Business and Management, 17(1), 23-37.

Rashid, A., Yousaf, S., \& Khaleequzzaman, M. (2017). Does Islamic Banking Strengthen Financial Stability? Empirical Evidence from Pakistan, International Journal of Islamic and Middle Eastern Finance and Management, 10(1), 202-240

Sadr, M. B. (1970). Al-Bank al-la Ribawi fi al-Islam. Kuwait: Jami Al-Naqi.

Shaukat, R. (2017). Regulatory Challenges of Islamic Banking in Pakistan. Journal of Islamic Thought and Civilization, 7(2), 78-98.

Siddiqi, M. N. (2004). Riba, Bank Interest, and the Rational of its Prohibition. Jeddah: Islamic Research and Training Institute, Islamic Development Bank.

Toutounchian, I. (2013). Islamic Money and Banking: Integrating Money in Capital Theory. Washington: Wiley Finance.

Zamil, N. (2014). An Empirical Investigation into the Problems and Challenges Facing Islamic Banking in Malaysia. (Doctoral dissertation) Cardiff Business School, Cardiff.

Zubair, H. (2014). Islamic Banking and Finance: An Integrative Approach. Oxford: Oxford University Press. 
This page is intentionally left blank 